\title{
Cleanup of industrial effluents containing heavy metals: a new opportunity of valorising the biomass produced by brewing industry
}

\author{
Eduardo V. Soares • Helena M. V. M. Soares
}

Received: 20 May 2013 / Revised: 14 June 2013 / Accepted: 15 June 2013 /Published online: 4 July 2013

(C) Springer-Verlag Berlin Heidelberg 2013

\begin{abstract}
Heavy metal pollution is a matter of concern in industrialised countries. Contrary to organic pollutants, heavy metals are not metabolically degraded. This fact has two main consequences: its bioremediation requires another strategy and heavy metals can be indefinitely recycled. Yeast cells of Saccharomyces cerevisiae are produced at high amounts as a by-product of brewing industry constituting a cheap raw material. In the present work, the possibility of valorising this type of biomass in the bioremediation of real industrial effluents containing heavy metals is reviewed. Given the autoaggregation capacity (flocculation) of brewing yeast cells, a fast and off-cost yeast separation is achieved after the treatment of metal-laden effluent, which reduces the costs associated with the process. This is a critical issue when we are looking for an effective, eco-friendly, and low-cost technology. The possibility of the bioremediation of industrial effluents linked with the selective recovery of metals, in a strategy of simultaneous minimisation of environmental hazard of industrial wastes with financial benefits from reselling or recycling the metals, is discussed.
\end{abstract}

\footnotetext{
E. V. Soares $(\square)$

Bioengineering Laboratory-CIETI, Chemical Engineering Department, ISEP-School of Engineering of Polytechnic Institute of Porto, Rua Dr António Bernardino de Almeida, 431, 4200-072 Porto, Portugal

e-mail: evs@isep.ipp.pt

E. V. Soares

IBB-Institute for Biotechnology and Bioengineering, Centre for Biological Engineering, Universidade do Minho, Campus de Gualtar, 4710-057 Braga, Portugal

H. M. V. M. Soares

REQUIMTE-Department of Chemical Engineering,

Faculty of Engineering of Porto University,

Rua Dr Roberto Frias, s/n, 4200-465 Porto, Portugal
}

Keywords Biosorption · Heavy metals bioremediation . Industrial effluents $\cdot$ Metals recycling $\cdot$ Saccharomyces cerevisiae $\cdot$ Yeast

\section{Introduction}

There are two main reasons why there is a demand for removing heavy metals from industrial wastewaters: (1) the toxicity of the heavy metals and (2) the possibility of its recovery. Certain metals (e.g. $\mathrm{Cu}, \mathrm{Fe}, \mathrm{Zn}, \mathrm{Co}$, and $\mathrm{Mn}$ ) are essential trace elements, at lower concentrations, necessary to the normal growth and cell metabolism; however, these metals, become toxic above specific threshold concentrations. Other metals, such as $\mathrm{Cd}, \mathrm{Hg}$, and $\mathrm{Pb}$ are non-essential for biological functions and are highly toxic, even at low concentrations (Gadd 2010). Metal ions (essential and non-essential), unlike organic compounds, are not biodegradable and can be accumulated through the food chain, creating an environmental hazard and posing a serious risk to public health (Naja and Volesky 2010a; Colin et al. 2012). Therefore, heavy metal pollution is one of the major concerns in industrialised countries. Leather and tanning industries, energy production, pigment and battery manufacturing, mining, metallurgical and electroplating industries are examples of industries that produce wastewaters containing heavy metals, such as $\mathrm{Cr}(\mathrm{III})$, $\mathrm{Cr}$ (VI) $\mathrm{Cu}$ (II), $\mathrm{Ni}(\mathrm{II})$, and $\mathrm{Zn}$ (II) ions at concentrations of up to 120 times higher than those permissible by law (Volesky 2003). As a result, industrial wastewaters can contain heavy metal concentrations higher enough to pose a serious environmental hazard; nevertheless, the metals present in these effluents are too low for being directly recovered.

The possibility of metals recovery is another important issue taking into account the increase in metal prices and the exhaustion of world mineral reserves. Besides saving natural resources, other striking environmental benefits of metals 
recycling (secondary metals production) include the reduction of energy needed to produce a ton of metal and the reduction of mining activities that disturb ecosystems (Dewulf et al. 2010).

Industrial effluents containing heavy metals should be pretreated before being discharged. For this purpose, different chemical (such as chemical precipitation and electrolytic recovery) and physical methods (ionic exchange resins and reverse osmosis) have been proposed (Naja and Volesky 2010b). However, the implementation of these technologies for the treatment of large volumes of effluents containing relatively low $(1-100 \mathrm{mg} / \mathrm{l})$ metals concentration, has been shown not able to remove the metals in order to meet the standards (alkaline precipitation) or presented high capital investments and running costs (ionic exchange resins and reverse osmosis) (Volesky 2001).

Since the 1980s, different types of biomass have been investigated in order to develop new methodologies to control inorganic pollution, which include cellulosic materials, seaweeds, and microorganisms. The potentialities of these types of biological materials were reviewed by Wang and Chen (2009). The use of Saccharomyces cerevisiae yeast cells, from different sources (baker, wine, and brewing) in the bioremediation of heavy metals was revised by Wang and Chen (2006) and more recently by Soares and Soares (2012); in the last work, the impact of physicochemical properties of the solution on the removal of metals, the role of chemical speciation for predicting and optimising the efficiency of metal removal and the selective recovery of the heavy metals were highlighted.

$S$. cerevisiae yeast cells obtained as a by-product from brewing industry is a relative underutilised raw material. The present work focus on the source and the application of brewing yeast cells, in the bioremediation of real industrial effluents loaded with heavy metals, which constitutes another possibility of valorisation of this type of biomass. The different possibility of the destiny of the yeast cells loaded with heavy metals, upon bioremediation, is also discussed.

\section{Yeast as a by-product of brewing industry}

As in most of the biotechnological processes, such as organic acids, antibiotics, and bio-ethanol production, part of the substrate is incidentally converted in biomass. This is also the case in the production of beer.

\section{Surplus yeast production}

In the brewing industry, yeast cells are inoculated into the oxygenated wort, in a process known in beer terminology as pitching. In the primary fermentation, wort fermentable sugars are converted into alcohol and carbon dioxide (wort attenuation) being produced a "green" or "immature" beer (Boulton and Quain 2001). During the fermentation process, yeast mass increases three-to sixfold, depending on the type of yeast, physiological conditions of the pitching yeast, wort oxygen concentration, and wort constituents (carbohydrates, amino acids, lipids, and minerals) (Huige 2006).

At the end of primary fermentation, yeast cells are removed (cropped) and stored up to 3 days, at low temperature $\left(2-4{ }^{\circ} \mathrm{C}\right)$ for subsequently being re-used (re-pitching) in many fermentation cycles. Before re-pitching, yeast cells are usually washed (with sterile water, food-grade quality acids, or with acid/ammonium persulfate) for removing any bacterial contaminants (Boulton and Quain 2001). The practice of serial cropping and re-pitching imposes to yeast cells several stresses (such as oxidative, osmotic, ethanol, hydrostatic starvation, and cold shock), which influences the viability and vitality; this leads to obtaining slurries (high concentrated cell suspension) with variable physiological conditions, which can originate inconsistent fermentation performance and affect the beer quality (Gibson et al. 2007). Therefore, serial re-pitching is usually restricted to $7-20$ fermentations; the number of serial re-pitchings depend on the strain robustness, company policy and production demands (Jenkins et al. 2003; Powell et al. 2003).

After their use, yeast cells are collected, as a by-product, which must be disposed of. Yeast surplus is the second major by product (after spent grain) in brewing industry. Typically, $0.2-0.3 \mathrm{~kg}$ of surplus yeast solids by every barrel (117 l) of beer brewed (Butzke and Singelton 2008). This means that a brewer with a production capacity of $3.2 \mathrm{hl} /$ year of beer will originate around 547-820 tons/year of surplus yeast solids.

\section{Current surplus yeast uses}

Yeast surplus is often merely seen as a waste material that has to be disposed of safely (Ferreira et al. 2010). For many brewers, a typical goal has been to identify the way of increasing the value of surplus yeast produced.

After being removed from green beer, yeast biomass is usually inactivated by thermal treatment and sold as animal feed (mainly for feeding swine) or a pet food supplement (for dogs and cats and in feeds for birds, fish, mink, and bees) because of its riche nitrogen, vitamin, and mineral content; in the USA, the use of yeast in pet foods is about 15,000-30,000 tons/year (Huige 2006). Brewers also mix yeast cells with spent grains and cold break, also called trub (precipitate, predominantly composed by protein and polyphenol formed during cooling of wort); this mixture is used in the rations for monogastric animals (Huige 2006). Yeast cells can also be included in formulations for fish nutrition (Ferreira et al. 2010). The bitter hop residues limits the use of brewing yeasts since it reduces palatability for humans or pets. The inclusion of yeast cells in food products, for humans, is also limited by the amount of nucleic acids (mainly RNA), present in yeast cells. In humans, RNA can be metabolised to uric acid, which can lead to gut. 
At present, surplus brewer's yeast biomass is, mainly, sold to inexpensive animal feed $(\sim 11 € /$ ton, with $18 \%$ dry weight). Others applications can be considered such as ingredient of microorganism culture media (yeast extract) or in the production of food ingredients (flavour enhancers, thickening, and emulsifying stabilisers) (Huige 2006; Ferreira et al. 2010). An ambitious route can be the recovery and purification of fine chemicals for use in pharmaceutical industries, analytical and biochemical research laboratories, such as enzymes, vitamins, amino acids, cytochromes and the components of DNA and RNA (Boulton and Quain 2001; Huige 2006); however, the last way has yet to be exploited because of the high initial investment required and the uncertainty of finding a market (Boulton and Quain 2001).

\section{Properties of brewer's yeast}

Heavy metal accumulation ability

Another possibility for using and valorising brewing yeast biomass is on the development of a technology for the treatment of laden-metals effluents. Removal experiences, carried out in aqua solutions, showed that brewing yeast cells have the ability to remove the main heavy metals that can be found in industrial wastewaters, namely: $\mathrm{Cd}(\mathrm{II}), \mathrm{Cr}(\mathrm{III})$, $\mathrm{Cu}(\mathrm{II}), \mathrm{Pb}(\mathrm{II}), \mathrm{Ni}(\mathrm{II}), \mathrm{Sr}(\mathrm{II})$, and $\mathrm{Zn}$ (II) (Avery and Tobin 1992; Marques et al. 1999; Ferraz et al. 2004; Han et al. 2006; Machado et al. 2009).

The application of $S$. cerevisiae biomass in the bioremediation of real electroplating effluents can be found in "Bioremediation of real industrial effluents."

\section{Sedimentation capacity}

S. cerevisiae strains used in brewing industry are typically flocculent. These yeast cells aggregate in multicellular masses, called flocs, in a spontaneous and reversible way, which rapidly settle in the medium where they are suspended. According to current knowledge, the flocculation of brewing yeasts occurs due to the interaction of a specific lectin-like protein (only present on flocculent cells) with the surface carbohydrate residues of the $\alpha$-mannan (receptors) of neighbouring cells (Soares 2011). It was described that $\mathrm{Ca}$ ions are directly involved in the binding of the flocculation lectin to the $\alpha$-mannan receptors (Veelders et al. 2010). Yeast flocculation is influenced by characteristics of the medium and the presence of specific FLO genes (such as FLO1, Lg-FLO1, FLO5, FLO8, FLO9, and FLO10) (Soares 2011). For a review of brewing yeast flocculation phenomena, the reader can consult the recent reviews (Soares 2011; Vidgren and Londesborough 2011; Panteloglou et al. 2012).
The use of flocculent yeast cells in the bioremediation of heavy metals offer several advantages: (a) higher metal accumulation than non-flocculent cells (Avery and Tobin 1992; Soares et al. 2002); most likely, heavy metals can also occupy the lectin Ca-binding sites and consequently increase metal removal (Soares et al. 2002); (b) the capacity to sediment, after treatment of effluents containing $\mathrm{Cu}, \mathrm{Ni}, \mathrm{Zn}, \mathrm{Cd}$, and $\mathrm{Cr}$ (Soares et al. 2002; Machado et al. 2008; Machado 2010); in fact, flocculation is a fast, efficient (more than $95 \%$ of cells can be settled within $5 \mathrm{~min}$ ) and of-cost process of cell separation (Machado et al. 2008); (c) yeast cells do not need to be immobilised; and (d) avoids the costs of equipment and energy demand required for the solid-liquid separation processes associated with the treatment of the effluent.

\section{Safe organism}

The yeast strains used in brewing industry belongs to $S$. cerevisiae sensu stricto complex (Vaughan-Martini and Martini 1998) being traditionally divided in two main groups: (a) ale brewing strains (S. cerevisiae), which classically rise to the top of fermenter at the end of the primary fermentation most likely due to the affinity for the $\mathrm{CO}_{2}$ bubbles (top fermentation) where they are skimmed off; and (b) lager strains (Saccharomyces pastorianus, also referred as Saccharomyces carlsbergensis for historical reasons), which settle in the bottom of the fermenter (bottom fermentation) (Stewart 2009; Soares 2011).

$S$. cerevisiae is a non-pathogenic microorganism, with a long tradition of application in the production of consumable products and has the "status" of "generally recognised as safe" organism by the US Food and Drug Administration. The well acceptance of brewing yeast cells, by public opinion, increases the possibility of the use of brewing biomass in the bioremediation of heavy metals.

\section{Removal of metals by yeast cells}

\section{Mechanisms}

Metals can be removed from solution, by yeast cells, by two main mechanisms: a passive process, called biosorption and a metabolism-dependent process, known as bioaccumulation (Fig. 1).

Biosorption can be defined as the physicochemical process wherein the metal (sorbate) interacts and is accumulated in the surface of microbial cells (biosorbent) (Gadd 2010). This property is displayed by both living and dead yeast cells, is fast (within minutes), and independent of metabolism. Biosorption does not require the addition of an energy source (Blackwell et al. 1995) and is attributed to the interaction with several functional groups of the mannoproteic 
Fig. 1 Mechanisms of removal of heavy metals by yeast cells. Surface (biosorption) and intracellular, metabolismdependent, accumulation (bioaccumulation) of heavy metals

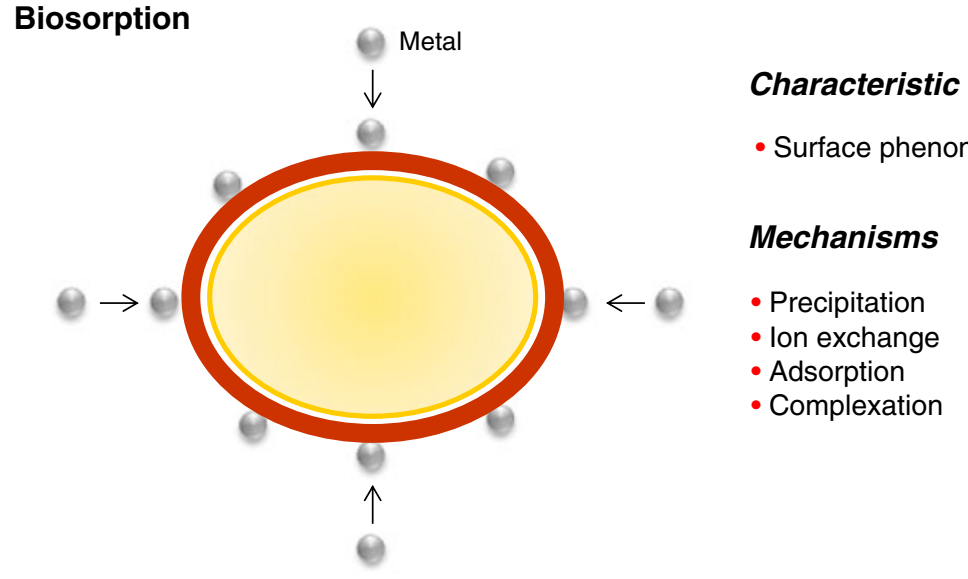

Bioaccumulation

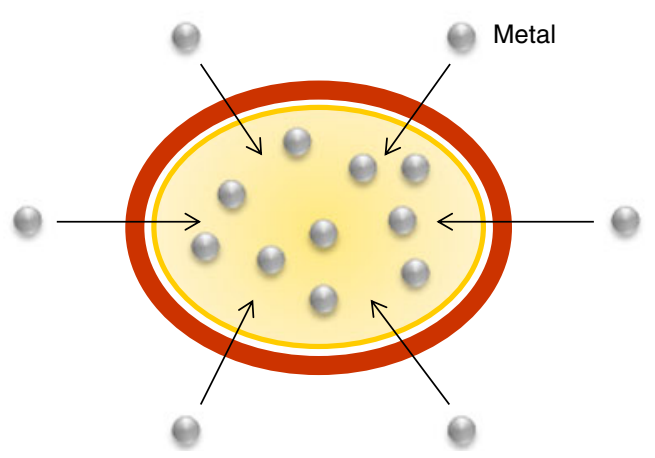

Characteristic

- Intracellular accumulation, metabolism-dependent

Mechanisms

- Active transport

- Pores or channels layer of yeast cell wall, namely carboxyl, amino, amide, hydroxyl, sulphydryl, and phosphate (Brady et al. 1994b, a; Blackwell et al. 1995; Wang 2002; Padmavathy et al. 2003; Han et al. 2006; Parvathi and Nagendran 2007; Machado et al. 2009). In this process, different passive metal sequestering processes can be involved, such as ion exchange (Brady and Duncan 1994b; Chen and Wang 2008; Dai et al. 2009; Amirnia et al. 2012), complexation, and adsorption (Parvathi et al. 2007; Dai et al. 2008).

In live yeast cells, after the initial surface (cell wall) metal accumulation (biosorption step), bioaccumulation can also occur. Bioaccumulation only occurs in metabolic active (live) cells (Fig. 1) and is a slow process (Blackwell et al. 1995), associated with the passage of the metals through the cell membrane by the action of $\mathrm{H}^{+}$-ATPase of the plasma membrane (Gadd and Sayer 2000). Metals can also be internalised via pores or channels, being subsequently intracellular accumulated (Gadd 2010). Bioaccumulation is affected by temperature and the presence of metabolic inhibitors (Blackwell et al. 1995).

Usefulness of using dead biomass

Although higher metal amounts can be removed from aqueous solutions (Avery and Tobin 1992; Mapolelo and Torto 2004; Ruta et al. 2010; Shah et al. 2010) or industrial effluents (Stoll and Duncan 1996) by live cells, the use of inactivated biomass shows several advantages: (a) the removal of metals is immune to the presence of toxics; (b) does not require an external energy source (nutrient supply); (c) yeast cells are easier stored as dried biomass; (d) biomass can be regenerated; (e) the process can operate in an analogous way to conventional ion-exchange technology; and (f) it is easier to recovery the metals from the biomass.

Flocculent brewing yeast cells heat inactivated, at $45^{\circ} \mathrm{C}$, retain the flocculation characteristics (Machado et al. 2008) and display a higher metal accumulation than the corresponding live cells (Machado et al. 2009). Heat treatment provokes a disruption of yeast cell membrane, which allows the passive intracellular accumulation of metals and the exposition of further metal-binding sites inside the cells (Fig. 2). An enhancement of the exposition of functional groups of yeast cell wall plus the biosorption of heavy metals may explain the increase of metals accumulation by dead biomass (Machado et al. 2009).

Influence of the physiochemical characteristics of the effluent on the metal removal

Bioremediation of heavy metals by yeast cells is affected by the physiochemical characteristics of the solution (namely: $\mathrm{pH}$, redox potential $\left(E_{\mathrm{h}}\right)$, and presence of other cations and 


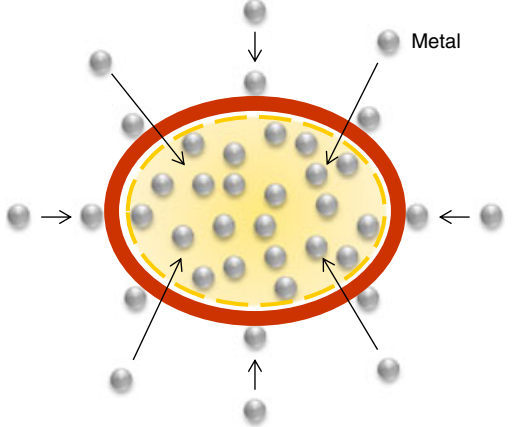

Characteristic

- Disruption of cell membrane

Mechanisms

- Biosorption$$
+
$$

- Intracellular metals

accumulation by a

metabolic independent

process

Fig. 2 Metals accumulation in heat-treated (dead) cells. In cells with membrane disrupted, surface and intracellular accumulation, metabolism-independent, occur

ligands in solution) and the chemical speciation of the metals (i.e. the different physicochemical forms of the metals in solution, which together make up its total concentration (Florence 1983)). Chemical speciation of metals is also affected by the physiochemical characteristics of the solution. These aspects were recently reviewed (Soares and Soares 2012).

Extremes $\mathrm{pH}$ values decrease removal of metals; $\mathrm{Cu}(\mathrm{II})$, $\mathrm{Cd}(\mathrm{II}), \mathrm{Pb}(\mathrm{II}), \mathrm{Ni}(\mathrm{II})$, and $\mathrm{Cr}(\mathrm{III})$ are maximum accumulated at $\mathrm{pH}$ values close to 5-6 (Brady and Duncan 1994a; Ferraz and Teixeira 1999; Özer and Özer 2003; Mapolelo and Torto 2004; Han et al. 2006; Parvathi and Nagendran 2007; Cui et al. 2010).

A typical example of the influence of the redox potential can be exemplified with $\mathrm{Cr}$. This metal occur as $\mathrm{Cr}$ (III) or $\mathrm{Cr}(\mathrm{VI})$ according to the $E_{\mathrm{h}}$ of the solution. $\mathrm{Cr}(\mathrm{III})$ takes place as trivalent cation or hydroxo complexes, whereas $\mathrm{Cr}(\mathrm{VI})$ occurs mainly as $\mathrm{HCrO}_{4}{ }^{-}$(at $\mathrm{pH} 2-5$ ) or $\mathrm{CrO}_{4}{ }^{2-}$, at $\mathrm{pH} \geq 8$ (Machado et al. 2010d). Effluents containing both Cr(III) and $\mathrm{Cr}(\mathrm{VI})$ forms can be treated using different strategies as it is discussed below (Bioremediation of real industrial effluents).

The presence of cations in solution like $\mathrm{Na}, \mathrm{K}, \mathrm{Ca}, \mathrm{Mg}$, and Mn can affect removal of metals by competing for the binding sites of yeast cells (Ferraz and Teixeira 1999; Marques et al. 1999; Mapolelo et al. 2005; Han et al. 2006).

Industrial effluents can present organic (such as EDTA) and/or inorganic ligands (carbonates, chlorides, fluorides, phosphates, nitrates, and sulphates) (Naja and Volesky 2010b); these ligands can also affect species distribution through complexation, which reduces metal availability to be removed by yeast cells (Machado et al. 2010a). It has been shown that the presence of fluorides, affected, deeply, $\mathrm{Cr}$ removal in an industrial effluent containing $\mathrm{Cr}(\mathrm{III}), \mathrm{Cu}(\mathrm{II})$, and $\mathrm{Ni}(\mathrm{II})$. Under these conditions, $\mathrm{Cr}$ (III) was mainly in a complexed form, being unavailable to be removed by yeast cells; however, a high removal of $\mathrm{Cu}(\mathrm{II})$ and $\mathrm{Ni}$ (II) was observed since more yeastbinding sites remained available to remove the other ions present in solution (Machado et al. 2011a).

Only the bioavailable metal, i.e. the free and labile metal will be removed by yeast cells (Hughes and Poole 1991;
Machado et al. 2010a, b). It was shown that by using chemical speciation modelling, it is possible to predict the availability of metals in solution and the removal efficiency of metals by the yeast cells (Machado et al. 2010a, b). It was also shown that the use of chemical speciation studies and statistical tools, as response surface methodology, allow the optimisation of the conditions of the effluent treatment, namely the $\mathrm{pH}$ of the solution and the biomass concentration, in order to improve the efficiency of metal removal (Ghorbani et al. 2008; Cojocaru et al. 2009; Machado et al. 2010a, b; Amirnia et al. 2012).

\section{Bioremediation of real industrial effluents}

In the last decade, a huge increase in the published research using different biological matrix for the bioremediation of heavy metals was observed (Gadd 2009). Most of the research work has been carried out in aqua solutions. Industrial effluents are usually much more complex and difficult to treat (Cojocaru et al. 2009; Mack et al. 2011).

The treatment of electroplating effluents containing $\mathrm{Cd}, \mathrm{Cu}$, $\mathrm{Cr}, \mathrm{Ni}$, and $\mathrm{Zn}$ was attempted using leaving yeast cells in a batch mode (Stoll and Duncan 1996). Formaldehyde crosslinked yeast cells were also used, in fixed-bed columns, to treat an electroplating rinse effluent containing $\mathrm{Cr}(\mathrm{VI})$ (Zhao and Duncan 1998); in both cases, no successful treatment of the effluents was achieved. More recently, non-viable (heat-treated) brewer's yeast cells were used to treat two effluents, in a batch mode, containing mainly $\mathrm{Cr}$ and $\mathrm{Sn}$ (and trace amounts of $\mathrm{Mn}, \mathrm{Fe}, \mathrm{Zn}, \mathrm{Ti}, \mathrm{Cd}, \mathrm{Co}$, and $\mathrm{Pb}$ ), from iron and steel industry; a removal of 29 and $32 \%$ of Sn and Cr, respectively, was described (van Wyk 2011). An efficient treatment of an real electroplating effluent containing nickel using flocculent brewing heat-inactivated biomass was described by Machado et al. (2010a).

Another possibility of effluents treatment consists on the use of chemical precipitation and, subsequently, yeast cells, in a polishing step. As industrial effluents usually present low $\mathrm{pH}$ $(\sim 2)$ value, the rise of $\mathrm{pH}$ to $\sim 6$ provokes the precipitation of part of $\mathrm{Cu}$ and $\mathrm{Cr}(\mathrm{III})$ as metal hydroxides (Machado et al. 2010b). At this $\mathrm{pH}$, the effluent does not affect the environment and corresponds to the optimum $\mathrm{pH}$ value for the bioremediation process as described above ("Influence of the physiochemical characteristics of the effluent on the metal removal"). Stoll and Duncan (1997) used this methodology for the treatment of an acid ( $\mathrm{pH}$ 1.5) electroplating effluent containing $\mathrm{Cd}, \mathrm{Cr}$, and $\mathrm{Zn}$, in excess; after raising the $\mathrm{pH}$ of up to 6 and settling of the sludge, the remaining solution was treated with immobilised, non-viable $S$. cerevisiae biomass, in continuous-flow-stirred bioreactors. Full treatment of the effluent was not achieved. Recently, the bioremediation of two electroplating effluents containing $\mathrm{Cu}, \mathrm{Ni}$, and $\mathrm{Zn}$ or $\mathrm{Cr}, \mathrm{Cu}$, 
Fig. 3 Bioremediation of industrial effluents, selective recovery of the metals, and regeneration of biomass. After the treatment of industrial effluent loaded with heavy metals, cell-liquid separation is achieved by flocculation. Subsequently, metals can be desorbed from yeast cells, biomass reused, and metals selectively recovered

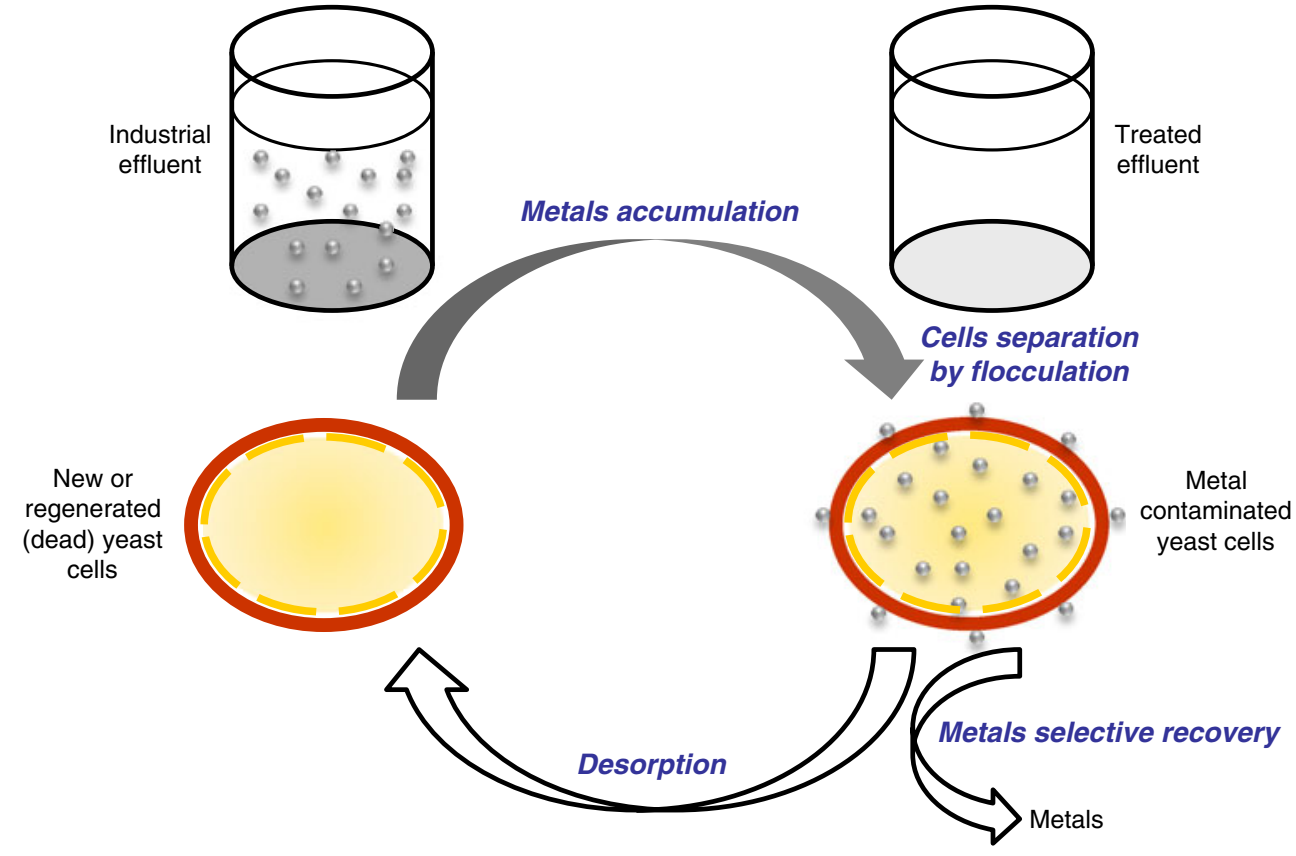

and $\mathrm{Ni}$ has been described; in both effluents, $\mathrm{pH}$ was adjusted to 6.0. In effluent with $\mathrm{Cr}(\mathrm{VI})$, the metal was previously reduced to $\mathrm{Cr}(\mathrm{III})$. Subsequently, effluents were submitted to a serial batch containing heat-inactivated flocculent brewing yeast cells. After the third batch, metal concentrations were lowered to values below the legal limits of discharge according to the USEPA; removals of $\geq 89 \%$, were attained for all metals (Machado et al. 2010b).

In the case of effluents containing, simultaneously, $\mathrm{Cr}(\mathrm{III})$ and $\mathrm{Cr}(\mathrm{VI})$, among other metals, two different strategies can be used: (1) previous reduction of $\mathrm{Cr}(\mathrm{VI})$ to $\mathrm{Cr}(\mathrm{III})$, with the subsequent $\mathrm{pH}$ adjustment and treatment with yeast cells, as described above (Machado et al. 2010b); (2) the selective removal or $\mathrm{Cr}(\mathrm{VI})$ at $\mathrm{pH}$ of $\sim 2$; afterwards, raising the $\mathrm{pH}$ of the effluent up to 6.0 and treatment with a serial batch of heat-inactivated yeast cells; this procedure also conduced to the bioremediation of the industrial effluent (Machado et al. 2010d).

\section{Fate of biomass loaded with heavy metals and recycling of metals}

An important issue associated with the bioremediation of heavy metals is the fate of the metals-contaminated biomass, after the cleanup of the effluents. Comparing with the removal of heavy metals, much lesser attention has been attributed to the destiny of the contaminated biomass. The problem associated with this toxic residue can be faced in a positive away through the selective recovery of the metals.

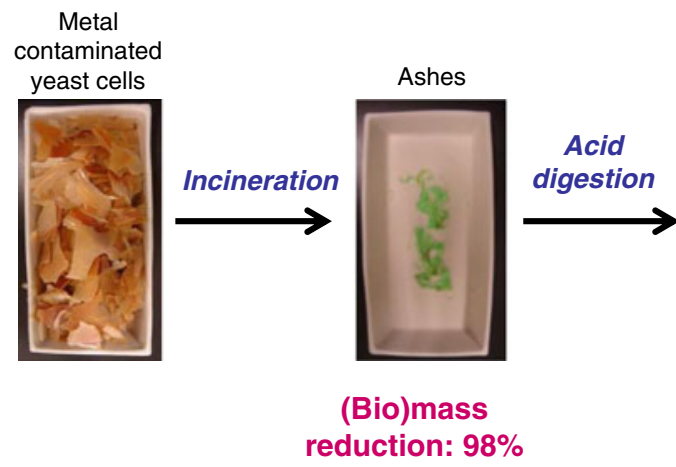

Fig. 4 Selective recovery of the metals from contaminated biomass. After the bioremediation of industrial effluent, biomass loaded with heavy metals is incinerated, which reduces the biomass in $98 \%$; then, ashes are acid digested, in a microwave-assisted process, ensuring a

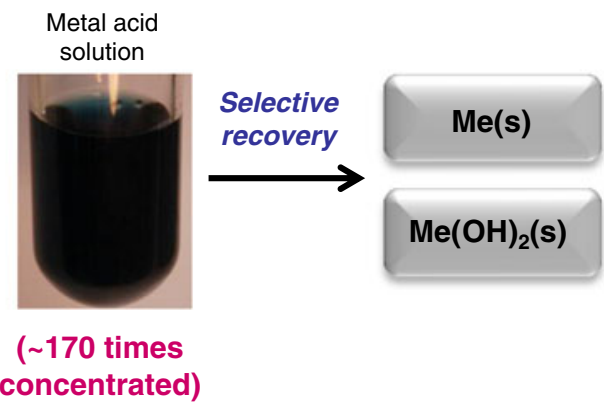

concentration of the metals at $\sim 170$ times; metals are recovered as pure metal $(\mathrm{Me})$ or as hydroxides $\left(\mathrm{Me}(\mathrm{OH})_{2}\right)$ using electrolytic and chemical processes 
In a green process, theoretically, the regeneration of the biomass and the simultaneous reclamation of the valuable metals is desirable (Fig. 3). With this aim, different eluants have been tested such as diluted inorganic and organic acids, bases and chelating agents (Strandberg et al. 1981; Wilhelmi and Duncan 1995, 1996; Ferraz et al. 2004; Padmavathy 2008; Yu et al. 2008; Kordialik-Bogacka 2011). Nevertheless, some practical difficulties have been observed, which compromise, strongly, the feasibility of the desorption process: (a) the deterioration of the yeast cells particularly when concentrated acids or prolonged exposure times were used; (b) the reduction of metal uptake through the successive biosorption/desorption cycles; and (c) the lower metal concentration capacity (Strandberg et al. 1981; Ferraz et al. 2004; Kordialik-Bogacka 2011). The last point is particularly important as the accumulation/desorption cycle should concentrate on metals, at least, $\sim 100$ times from the initial concentration present in the wastewaters (Naja et al. 2010).

Alternatively, biomass loaded with metals can be dissolved with strong acids or incinerated. The last possibility seems to be well suited since the incineration of dried yeast biomass, at $550{ }^{\circ} \mathrm{C}$, conduces to a strong reduction ( 83 to $98 \%$ ) of the residues (ashes) which can be, later on, immobilised in an inert support or land field. On the other hand, ashes can also be acid digested, in a microwave-assisted process, originating a concentrated metals solution ( $\sim 170$ times more concentrated than initial concentration present in the effluents) (Machado et al. 2010c) (Fig. 4). This acid metal solution, obtained after the digestion of the ashes, is much more concentrated that those obtained from the acid dissolution of the biomass; this fact increases the feasibility of the subsequent metals recovery step (Machado et al. 2010c).

Metals can be selectively recovered with a high yield (>99\%) and purity (>92-99.9\%) by combining $\mathrm{Cu}$ electrolysis with alkaline precipitation (Machado et al. 2010c, 2011b). The metals can be sold (as pure metal or its hydroxides) or sent back and reused in the electroplating process.

\section{Concluding remarks}

Brewing biomass seems to be a good alternative for the low-cost bioremediation of heavy metals, in a direct or in a "polishing" wastewater treatment step. Recent works, carried out at a laboratory scale, demonstrated the usefulness of using heatinactivated flocculent brewing cells for detoxifying complex industrial effluents loaded with several heavy metals. This application constitutes another possibility of valorising the surplus brewing yeast biomass. Using a mild-heat treatment $\left(45^{\circ} \mathrm{C}\right)$, yeast cells retain flocculation characteristics and enhanced metals accumulation capacity when compared with the respective live cells. Exploiting the intrinsic flocculation capacity of the brewing yeast cells, an efficient metal removal with a fast and off-cost yeast separation is achieved. The bioremediation of industrial effluents should be associated with the selective recovery of metals, as it allows that companies obtain a financial benefit linked with selling or recycling metals, without the generation of wastes.

\section{References}

Amirnia S, Margaritis A, Ray MB (2012) Adsorption of mixtures of toxic metal ions using non-viable cells of Saccharomyces cerevisiae. Adsorpt Sci Technol 30:43-63

Avery SV, Tobin JM (1992) Mechanism of strontium uptake by laboratory and brewing strains of Saccharomyces cerevisiae. Appl Environ Microbiol 58:3883-3889

Blackwell KJ, Singleton I, Tobin JM (1995) Metal cation uptake by yeast: a review. Appl Microbiol Biotechnol 43:579-584

Boulton C, Quain D (2001) Brewing yeast and fermentation. Blackwell, Oxford

Brady D, Duncan JR (1994a) Bioaccumulation of metal-cations by Saccharomyces cerevisiae. Appl Microbiol Biotechnol 41:149-154

Brady D, Duncan JR (1994b) Cation loss during accumulation of heavy metal cations by Saccharomyces cerevisiae. Biotechnol Lett 16:543-548

Brady D, Stoll A, Duncan JR (1994a) Biosorption of heavy metal cations by non-viable yeast biomass. Environ Technol 15:429-438

Brady D, Stoll A, Duncan JR (1994b) Chemical and enzymatic extraction of heavy metal binding polymers from isolated cell walls of Saccharomyces cerevisiae. Biotechnol Bioeng 44:297-302

Butzke CE, Singelton VL (2008) Yeasts. In: Othmer DF, Kirk RE (eds) Kirk-Othmer food and feed technology, vol 2. Wiley, New York, pp 711-744

Chen C, Wang JL (2008) Investigating the interaction mechanism between zinc and Saccharomyces cerevisiae using combined SEM-EDX and XAFS. Appl Microbiol Biotechnol 79:293-299

Cojocaru C, Diaconu M, Cretescu I, Savic J, Vasic V (2009) Biosorption of copper(II) ions from aqua solutions using dried yeast biomass. Colloid Surf A-Physicochem Eng Asp 335:181-188

Colin VL, Villegas LB, Abate CM (2012) Indigenous microorganisms as potential bioremediators for environments contaminated with heavy metals. Int Biodeterior Biodegrad 69:28-37

Cui LZ, Wu GP, Jeong TS (2010) Adsorption performance of nickel and cadmium ions onto brewer's yeast. Can J Chem Eng 88:109-115

Dai SJ, Wei DZ, Zhou DQ, Jia CY, Wang YJ, Liu WG (2008) Removing cadmium from electroplating wastewater by waste Saccharomyces cerevisiae. Trans Nonferrous Metals Soc China 18:1008-1013

Dai QW, Dong FQ, Zhang W (2009) The biosorption effect and mechanism of $\mathrm{Pb}$ (II) on waste beer yeast. In: ICEET: Proceedings of the 2009 International Conference on Energy and Environment Technology, vol 2, Leee Computer Soc, Los Alamitos, pp 827-830

Dewulf J, Van der Vorst G, Denturck K, Van Langenhove H, Ghyoot W, Tytgat J, Vandeputte K (2010) Recycling rechargeable lithium ion batteries: critical analysis of natural resource savings. Resour Conserv Recycl 54:229-234

Ferraz AI, Teixeira JA (1999) The use of flocculating brewer's yeast for $\mathrm{Cr}(\mathrm{III})$ and $\mathrm{Pb}(\mathrm{II})$ removal from residual wastewaters. Bioprocess Eng 21:431-437

Ferraz AI, Tavares T, Teixeira JA (2004) Cr(III) removal and recovery from Saccharomyces cerevisiae. Chem Eng J 105:11-20

Ferreira I, Pinho O, Vieira E, Tavarela JG (2010) Brewer's Saccharomyces yeast biomass: characteristics and potential applications. Trends Food Sci Technol 21:77-84

Florence TM (1983) Trace-element speciation and aquatic toxicology. Trac-Trends Anal Chem 2:162-166 
Gadd GM (2009) Biosorption: critical review of scientific rationale, environmental importance and significance for pollution treatment. J Chem Technol Biotechnol 84:13-28

Gadd GM (2010) Metals, minerals and microbes: geomicrobiology and bioremediation. Microbiology 156:609-643

Gadd GM, Sayer JA (2000) Influence of fungi on the environmental mobility of metals and metalloids. In: Lovley DR (ed) Environmental micrometal interactions. ASM Press, Washington D.C., pp 237-256

Ghorbani F, Younesi H, Ghasempouri SM, Zinatizadeh AA, Amini M, Daneshi A (2008) Application of response surface methodology for optimization of cadmium biosorption in an aqueous solution by Saccharomyces cerevisiae. Chem Eng J 145:267-275

Gibson BR, Lawrence SJ, Leclaire JPR, Powell CD, Smart KA (2007) Yeast responses to stresses associated with industrial brewery handling. FEMS Microbiol Rev 31:535-569

Han RP, Li HK, Li YH, Zhang JH, Xiao HJ, Shi J (2006) Biosorption of copper and lead ions by waste beer yeast. J Hazard Mat 137:1569-1576

Hughes MN, Poole RK (1991) Metal speciation and microbialgrowth - the hard (and soft) facts. J Gen Microbiol 137:725-734

Huige NJ (2006) Brewery by-products and effluents. In: Priest FG, Stewart GG (eds) Handbook of brewing. CRC Press, Boca Raton, pp 655-713

Jenkins CL, Kennedy AI, Hodgson JA, Thurston P, Smart KA (2003) Impact of serial repitching on lager brewing yeast quality. J Am Brew Chem 61:1-9

Kordialik-Bogacka E (2011) Cadmium and lead recovery from yeast biomass. Cent Eur J Chem 9:320-325

Machado MD (2010) Removal and selective recovery of heavy metals from electroplating effluents. Ph.D. thesis, Porto University, Porto

Machado MD, Santos MSF, Gouveia C, Soares HMVM, Soares EV (2008) Removal of heavy metals using a brewer's yeast strain of Saccharomyces cerevisiae: the flocculation as a separation process. Bioresour Technol 99:2107-2115

Machado MD, Janssens S, Soares HMVM, Soares EV (2009) Removal of heavy metals using a brewer's yeast strain of Saccharomyces cerevisiae: advantages of using dead biomass. J Appl Microbiol 106:1792-1804

Machado MD, Soares EV, Soares HMVM (2010a) Removal of heavy metals using a brewer's yeast strain of Saccharomyces cerevisiae: chemical speciation as a tool in the prediction and improving of treatment efficiency of real electroplating effluents. J Hazard Mat 180:347-353

Machado MD, Soares EV, Soares HMVM (2010b) Removal of heavymetals using a brewer's yeast strain of Saccharomyces cerevisiae: application to the treatment of real electroplating effluents containing multielements. J Chem Technol Biotechnol 85:1353-1360

Machado MD, Soares EV, Soares HMVM (2010c) Selective recovery of copper, nickel and zinc from ashes produced from Saccharomyces cerevisiae contaminated biomass used in the treatment of real electroplating effluents. J Hazard Mat 184:357-363

Machado MD, Soares HMVM, Soares EV (2010d) Removal of chromium, copper and nickel from an electroplating effluent using a flocculent brewer's yeast strain of Saccharomyces cerevisiae. Water Air Soil Poll 212:199-204

Machado MD, Soares EV, Soares HMVM (2011a) Impact of fluorides on the removal of heavy metals from an electroplating effluent using a flocculent brewer's yeast strain of Saccharomyces cerevisiae. Chem Speciation Bioavail 23:237-242

Machado MD, Soares EV, Soares HMVM (2011b) Selective recovery of chromium, copper, nickel, and zinc from an acid solution using an environmentally friendly process. Environ Sci Pollut Res 18:1279-1285

Mack CL, Wilhelmi B, Duncan JR, Burgess JE (2011) Biosorptive recovery of platinum from platinum group metal refining wastewaters by immobilised Saccharomyces cerevisiae. Water Sci Technol 63:149-155
Mapolelo M, Torto N (2004) Trace enrichment of metal ions in aquatic environments by Saccharomyces cerevisiae. Talanta 64:39-47

Mapolelo M, Torto N, Prior B (2005) Evaluation of yeast strains as possible agents for trace enrichment of metal ions in aquatic environments. Talanta 65:930-937

Marques PA, Pinheiro HM, Teixeira JA, Rosa MF (1999) Removal efficiency of $\mathrm{Cu}^{2+}, \mathrm{Cd}^{2+}$ and $\mathrm{Pb}^{2+}$ by waste brewery biomass: $\mathrm{pH}$ and cation association effects. Desalination 124:137-144

Naja GM, Volesky B (2010a) Toxicity and sources of Pb, Cd, Hg, Cr, As and radionuclides in the environment. In: Wang LK, Chen JP, Hung YT, Shammas NK (eds) Handbook on heavy metals in the environment. CRC Press, Boca Raton, pp 13-61

Naja GM, Volesky B (2010b) Treatment of metal-bearing effluents: removal and recovery. In: Wang LK, Chen JP, Hung YT, Shammas NK (eds) Handbook on heavy metals in the environment. CRC Press, Boca Raton, pp 247-291

Naja GM, Murphy V, Volesky B (2010) Biosorption, metals. In: Flickinger M (ed) Encyclopedia of Industrial Biotechnology: bioprocess, bioseparation, and cell technology. Wiley, New York, pp 1-29

Özer A, Özer D (2003) Comparative study of the biosorption of Pb(II), $\mathrm{Ni}(\mathrm{II})$, and $\mathrm{Cr}(\mathrm{VI})$ ions onto $S$. cerevisiae: determination of biosorption heats. J Hazard Mat B 100:219-229

Padmavathy V (2008) Biosorption of nickel(II) ions by baker's yeast: kinetic, thermodynamic and desorption studies. Bioresour Technol 99:3100-3109

Padmavathy V, Vasudevan P, Dhingra SC (2003) Biosorption of nickel(II) ions on Baker's yeast. Process Biochem 38:1389-1395

Panteloglou AG, Smart KA, Cook DJ (2012) Malt-induced premature yeast flocculation: current perspectives. J Ind Microbiol Biotechnol 39:813-822

Parvathi K, Nagendran R (2007) Biosorption of chromium from effluent generated in chrome-electroplating unit using Saccharomyces cerevisiae. Sep Sci Technol 42:625-638

Parvathi K, Nagendran R, Nareshkumar R (2007) Lead biosorption onto waste beer yeast by-product, a means to decontaminate effluent generated from battery manufacturing industry. Electron $\mathrm{J}$ Biotechnol 10:92-105

Powell CD, Quain DE, Smart KA (2003) The impact of brewing yeast cell age on fermentation performance, attenuation and flocculation. FEMS Yeast Res 3:149-157

Ruta L, Paraschivescu C, Matache M, Avramescu S, Farcasanu IC (2010) Removing heavy metals from synthetic effluents using "kamikaze" Saccharomyces cerevisiae cells. Appl Microbiol Biotechnol 85:763-771

Shah D, Shen MWY, Chen W, Da Silva NA (2010) Enhanced arsenic accumulation in Saccharomyces cerevisiae overexpressing transporters Fps1p or Hxt7p. J Biotechnol 150:101-107

Soares EV (2011) Flocculation in Saccharomyces cerevisiae: a review. J Appl Microbiol 110:1-18

Soares EV, Soares H (2012) Bioremediation of industrial effluents containing heavy metals using brewing cells of Saccharomyces cerevisiae as a green technology: a review. Environ Sci Pollut R 19:1066-1083

Soares EV, De Coninck G, Duarte F, Soares H (2002) Use of Saccharomyces cerevisiae for $\mathrm{Cu}^{2+}$ removal from solution: the advantages of using a flocculent strain. Biotechnol Lett 24:663-666

Stewart GG (2009) The Horace Brown medal lecture: forty years of brewing research. J Inst Brew 115:3-29

Stoll A, Duncan JR (1996) Enhanced heavy metal removal from waste water by viable, glucose pretreated Saccharomyces cerevisiae cells. Biotechnol Lett 18:1209-1212

Stoll A, Duncan JR (1997) Implementation of a continuous-flow stirred bioreactor system in the bioremediation of heavy metals from industrial waste water. Environ Pollut 97:247-251

Strandberg GW, Shumate SE II, Parrot JR Jr (1981) Microbial cells as biosorbents for heavy metals: accumulation of uranium by 
Saccharomyces cerevisiae and Pseudomonas aeruginosa. Appl Environ Microbiol 41:237-245

van Wyk CS (2011) Removal of heavy metals from metal-containing effluent by yeast biomass. Afr J Biotechnol 10:11557-11561

Vaughan-Martini A, Martini A (1998) Saccharomyces Meyen ex Reess. In: Kurtzman CP, Fell JW (eds) The yeasts: a taxonomic study. Elsevier, Amsterdam, pp 358-371

Veelders M, Bruckner S, Ott D, Unverzagt C, Mosch HU, Essen LO (2010) Structural basis of flocculin-mediated social behavior in yeast. Proc Natl Acad Sci USA 107:22511-22516

Vidgren V, Londesborough J (2011) 125th Anniversary Review: yeast flocculation and sedimentation in brewing. J Inst Brew $117: 475-487$

Volesky B (2001) Detoxification of metal-bearing effluents: biosorption for the next century. Hydrometallurgy 59:203-216

Volesky B (2003) Sorption and biosorption. BV Sorbex, Inc, Montreal
Wang JL (2002) Biosorption of copper(II) by chemically modified biomass of Saccharomyces cerevisiae. Process Biochem 37:847-850

Wang J, Chen C (2006) Biosorption of heavy metals by Saccharomyces cerevisiae: a review. Biotechnol Adv 24:427-451

Wang JL, Chen C (2009) Biosorbents for heavy metals removal and their future. Biotechnol Adv 27:195-226

Wilhelmi BS, Duncan JR (1995) Metal recovery from Saccharomyces cerevisiae biosorption columns. Biotechnol Lett 17:1007-1012

Wilhelmi BS, Duncan JR (1996) Reusability of immobilised Saccharomyces cerevisiae with successive copper adsorption-desorption cycles. Biotechnol Lett 18:531-536

Yu JX, Tong M, Sun XM, Li BH (2008) Enhanced and selective adsorption of $\mathrm{Pb}^{2+}$ and $\mathrm{Cu}^{2+}$ by EDTAD-modified biomass of baker's yeast. Bioresour Technol 99:2588-2593

Zhao M, Duncan JR (1998) Column sorption of Cr(VI) from electroplating effluent using formaldehyde cross-linked Saccharomyces cerevisiae. Biotechnol Lett 20:603-606 